\title{
WRITING RADICAL LABORATORY ANIMAL HISTORIES
}

by Tone Druglitrø

In recent years historians have called for a radical historicizing to broaden the perspectives, stories and actors that are usually made subjects of historical investigations. The appeals have mainly come from scholars that have been concerned with historicizing nature and human-nature relations. But what does radical historicizing entail and why do we need it? The article presents a reflexive review of current methods and perspectives in the social sciences and humanities that have affected my own engagement with the history of laboratory animals in Norway. It presents an argument for doing historiography that reflects contemporary scholarly concerns on representation. Rather than seeking to "give animals histories of their own" I propose that radical historicizing should include writing histories of the entanglement and disentanglement of humans and other things and beings. This does not then involve a shift to writing animal stories for the sake of animals, but to write stories where humans and animals are considered mutually shaped and affected by each other, and how these interactions have world-transforming effects.

a) attribution - give appropriate credit, provide a link to the license, and indicate if changes were made.

b) share alike - any remixing, transformation or building upon the material must itself be published under the same license as the original. 


\section{N}

NORDIC JOURNAL

of Science and Technology Studies

\section{Introduction}

In recent years historians have called for a radical historicizing to broaden the perspectives, stories and actors that are usually made subjects of historical investigations. The appeals have mainly come from scholars that have been concerned with historicizing nature and human-nature relations. But what does radical historicizing entail and why do we need it? In the anthology Representing Animals (Rothfels 2002) Erica Fudge, cultural historian of human-animal interactions and renaissance offers a left-handed blow to past and contemporary historicizing of animals. In her essay Fudge challenges us to rethink historical work involving animals and to consider what ethical work is performed by a "history of animals" that on the surface appears to be just another aspect of human history. What are the problematic aspects of animal histories Fudge is alerting us to? What does she mean by the history of animals appearing as only aspects of human history, and how does it relate to the historians ethical responsibility in the present? How are we to write animals in historical work?

The calls for radical historicizing propose reflexivity in our studies involving animals; that is, to reflect on how we engage (or fail to engage) with animals in the histories we write and how we engage with them in relation to, situated in and as part of ongoing debates and controversies involving animals. This is not only important because of disciplinary reflexivity but also, Fudge argues, because "the history of animals is a necessary part of our reconceptualization of ourselves as humans" (2002: 5). In this way she invites a shift from human-focused histories to histories where animals are placed next to humans. Radical historicizing thus involves a commitment to reformulate methodological assumptions and implications for how non-humans are or should be included in our studies. Such methodological concerns on historical writing have been presented and deliberated in the fields of STS and history of science represented (in addition to Fudge) particularly by Asdal (2011), Haraway (1989) and Latour (2005). Even though all of these scholars, including Fudge, are concerned with constructions and materiality and how representations are inherently linked to materiality, the latter three mobilize a somewhat different version of radical historicizing which involves specific methodological commitments on how we are to widen the scope of who gets to be enacted as part of our stories and in what ways.

In this article I seek to build on Fudge's call for radical historicizing, but place her arguments in dialogue with methodological assumptions developed in the fields of STS and history of science. I will do so by discussing methodological and theoretical strategies in my own work where I have traced the development and establishment of a laboratory animal science industry in Norway in the period 1950 s to the 1980s. Further, I will highlight and discuss work I have drawn upon and been inspired by to reflect on the methodological resources offered by STS and history of science for doing radical historicizing. Thus, the article presents a reflexive review of current methods and perspectives in the social sciences and humanities that have affected my engagement with the history of laboratory animals. It presents an argument for doing historiography that reflects contemporary scholarly concerns on representation: Rather than seeking to "give animals histories of their own" I propose that radical historicizing should include writing histories of the entanglement and disentanglement of humans and other things and beings. This does not then involve a shift to writing animal stories for the sake of animals, but to write stories where humans and animals are considered mutually shaped and affected by each other, and how these interactions have world-transforming effects.

\section{"Animal histories" - wanted utopia or not?}

Animal histories have often been deemed impossible as they fail to include the two fundamental ingredients of history: text and temporality. Animals do not leave documents that capture their histories and they do not have a sense of time as we humans have. Rather, they have tended to be "used" in historical accounts to show something particular about human practices and worlds and as such made into powerful symbols (with an emphasis on symbol rather than "real"). In reality then the history of animals has been the history of human attitudes towards animals (Fudge 2002: 5). Fudge identifies the problem of animal histories as linked to the discussions within history between empiricism and post-structuralism where the former believe that the past is recoverable to history through an objective analysis of its documents, while the latter sees history as constructed. The difference affects how historians can know and understand the past (2002: 6). This is a very important point and is as I see it at the heart of disciplinary debates on the subject of history in general: How to reconstruct the past that fits reality the best. For instance, the distinction presented by Fudge sounds familiar when thinking of the debates on the relationship between STS and history of science foregrounded by Lorraine Daston (2009), Sheila Jasanoff (2000) and Peter Dear \& Sheila Jasanoff (2010).

The history of science have been more in line with the empiricist approach in that they have been concerned with understanding science on its own terms, in specific historical moments, by attending to its practices. STS on the other hand follows the constructivist approach (or we better call it a post-constructivist approach as it should not be mistaken with social constructivism, see Asdal 2003). Studies in STS have shown that by regarding science as a set of cultural practices we also need to reject notions that scientific and technological development work as cumulative evolutionary 
processes; Science and society is shaped in contingent, local, and specific practices. Further, STS is influenced by critical traditions such as feminism and other social movements. This has involved the promotion of critical questions such as what stories are told by whom and of who, and assertions that there exist other promising realities in addition to science, challenging and shaping scientific development. Tracing practices and heterogeneous actors will offer more forceful representations of how science works and how it is organized and accepted in society. From an actor-network-theory (ANT) perspective we would ask: Is there only one reality? Is the past made up of one real history? Isn't it plausible that rather than one real story there are several (often incoherent) histories to tell depending on the questions you ask, the actors you follow, and the connections you trace?

When investigating the efforts of establishing a laboratory animal science industry and producing particular laboratory animals, I attended to a large and heterogeneous body of texts. I often felt like the hard-working, trail-sniffing ant Latour talks about in Reassembling the Social (2005: 9) when "knitting" the history together from blueprints, notes, White papers, letters, books, pamphlets, reports, bulletins, newsletters, academic publications, comic strips, photographies and so forth. Latour reminds us in his (re-)introduction to ANT that it was never meant to be a theoretical model and those who relate to it as such have a tendency to misunderstand the real potential of ANT; ANT is an empirical method: "...the historical name is 'actor-network-theory', a name that is so awkward, so confusing, so meaningless that it deserves to be kept... I was ready to drop this label for more elaborate ones...until someone pointed out to me that the acronym A.N.T. was perfectly fit for a blind, myopic, workaholic, trail-sniffing, and collective traveler. An ant writing for other ants" (p. 9). Knitting "my" story together involved a constant tracing of connections between people, things and animals. Sometimes the animals could be present in the texts even though they were not mentioned or easily identified. For instance, in the statistics based on the distribution and care of laboratory animals or in the blueprints of the animal house. In other texts there were elaborations on different species of animals or concerns regarding the housing of the animals. Further, some texts were interesting to analyze not only by content but also by form, such as the bureaucratic make up of the Animal Protection Act (1974).

The methodological principles offered by ANT enabled an "ethnographic" approach to doing historical investigations through texts in similar ways as anthropologists do real-time research and observations. Interestingly, STS scholars have made the statement of "follow the actors" a mantra for doing real-time research but have missed the opportunity to think of this in terms of historical work. Kristin Asdal has pointed to this in a recent article in Science in Context, where she proposes that ANT can be read as a way of investigation that "ought to be cherished as the historian's method"; Even if historians have tended to see "context" as their most precious tool, whereas the trademark of actor-network theory has been the opposite, namely to contest context (2012: 381).
What Asdal proposes is to turn the conventional historian's way of working on its head, as does Fudge. However, drawing upon ANT resources Asdal is more explicit about how to go about doing this. She claims that we can just as well trace practices by attending to texts as we can as ethnographers following the actors in real time. In a recent book Tekst og historie (2010) she and other humanist scholars illustrate how texts are not only material objects, but must be read generously as events, as actions, as ways and means of changing the realities in which they are made part of. Asdal has shown how this works as an extremely fruitful method in her book Politikkens natur - naturens politikk from 2011 where she tells the story of Norwegian controversies on different nature issues by attending to the interlinked practices of science, politics and the public. By mobilizing ANT as an empirical philosophy that helps her to trace how actors come together and form different nature objects, she is also able to trace how these different assemblages enact different, but related, contexts/versions of reality.

If we look at studies working at the intersections of history of science, STS and cultural history they have been very concerned with overcoming the issues of merely using animals by taking into account the mutually shaping material and semiotic practices in which animals and humans interact. In studies of laboratory animals/organisms this has been particularly evident. I pay much of my debt to these studies in terms of providing perspectives on standardization practices in science: For instance, Robert Kohler's (1994) book on the Drosophila fly and the development of genetics in T.H. Morgan's laboratory reveal the material practices of the laboratory and the work that goes into standardizing an organism for science. Kohler's objective is not primarily to write a history about the fly however the flies are given attention in his book as curious research materials for Morgan and his team. Kohler tells the story both to say something about the nature and norms of scientific work and organization of work and to say something about the emergence of genetics as a particular scientific discipline dependent on the fly. Still, a relevant critique of Kohler is that the fly is left to do the dirty work in the dark corners of the story, while others like T.H. Morgan gets the leading act as hero.

Karen Rader (2004) has in similar ways told the story of the JAX mouse and the work of CC Little in standardizing and establishing the world's first trademarked strain of laboratory mice. Rader is more conscious about how she represents the mice in her book, for instance by showing how the breeding of mice were linked to cultural practices of mouse fancying and that the meeting of cultural practices and science was central to producing the standardized mouse. By making a link between cultural and scientific practices, the mouse is portrayed as the complex result of negotiations between heterogeneous actors (including the mice themselves). The mice is highlighted in Rader's story as the heroes, however are given the role as understudies in the narrative. While Rader proposed the JAX mouse to represent a standard that were carried as a rallying symbol for genetic science, she did not consider how and when particular version of the JAX mouse was present and when it 


\section{N}

NORDIC JOURNAL

of Science and Technology Studies

was not. What is often left out in the narratives are explicit reflections and considerations of how the animal enters or disappears from the story - when is it at the center, when is it decentered, when does it matter, and in what ways? Taking these aspects into the narrative tells us something about the animal and the different human-animal relations in particular moments and situated practices, i.e. what humans and animals are in their multiplicity.

Robert G. W. Kirk (2005) was particularly concerned with the issue of what a laboratory animal is in his thesis on laboratory animal science in the UK in the period between the 1930s and the 1970 s. Kirk head on criticizes current sociological and historical research on laboratory animals and their depiction as deindividualised technologies in science. Sociological as well as several history of science studies have been satisfied with concluding that animals turn into technologies when entering the scientific laboratory (i.e. Birke et al 2007; Lynch 1988). The consequence of this these studies claim, is that animals are deprived of any moral status in the laboratory, thus the natural animal disappears and all that is left is technology. Kirk challenges these conclusions in his thesis by showing how laboratory animals were far from deindividualised technologies in the making of large-scale public health research programs in the $1940 \mathrm{~s}$. He show how new standards of laboratory animal quality became

\section{Transforming humans and animals}

Drawing upon STS and history of science studies, radical historicizing has in my own work involved a concern with how human-animal practices emerge, how they are made sense of, and how spaces and contexts of human-animal relations have been shaped and organized by these interactions. I have traced the establishment of a laboratory animal science and industry in Norway between 1950 s and 1980 s. The aim of the project was to understand what a laboratory animal was and how it was transformed in a particular historical practice. The research questions were framed around the animal however directed at the human practices in which animals were involved. I sought to understand how the practices of using animals in biomedical research had been shaped and maintained over time; what were the challenges, and what values were integrated in the practices of producing, caring for, and using animals for research?

The question of what is a laboratory animal thus pointed to a range of other technoscientific, cultural and historically situated processes including humans, animals, politics, technologies, and scientific methods and theories. For instance, the establishment of a laboratory animal science industry was intrinsically linked to public health politics such as the testing and control of vaccines and industrial products, and diagnosing diseases. These public health programs became increasingly based on animal experimentation as animal experimentation had become intrinsic to the practices of biomedicine (that is, the combination of biology, veterinary and medical sciences) during the past decades. Scientific knowledge production in the biomedical sciences was seen as a crucial part interlinked with new standards for welfare that helped individualize the animals. Each animal needed careful construction and attention in order to perform well as a laboratory animal. Kirk however ends his story before he can show us how the individualization of the animal was done in practice. What work does an "individualized laboratory animal" do, compared to, say, a deindividualised?

All of the above histories of animals are really stories about something more than the animal. In her essay Fudge emphasizes the value of attending to the material practices and use of animals throughout history: "it is in use - in the material relation with the animal - that representation must be grounded", she writes (2002:7). Maybe the crucial question then is not if or how the stories of animals are animal histories or not, but rather what kind of questions and approaches are needed in order for us to include animals in our histories that reveal the crucial importance of animals (both philosophically, socially and materially) in the making of our realities. In her work Haraway (e.g. 2008) invites us to understand animal and human histories as co-entangled and co-emerging, as modes of becoming with. In such a view, animal histories per se represent a utopia that is not wanted because what we should do is rather to tell animal stories in interaction with humans.

of clinical practices, and clinical practice was increasingly based on work in the laboratory. The need for purpose-bred laboratory animals was pressing as many scientists used animals that had unknown origin and history of health and disease, and experiments were deemed to be unreliable as the physiological and pathological processes in the animal had not been controlled from the start.

These unknown factors challenged how scientists could know what really affected particular experimental results. Routine testing and production of vaccines and diagnosing disease involved repetitive experiments and comparison between a body of animals of more or less identical genetic and pathogenic composition. This meant that the animals needed not only to be of known origin, genetic and pathogenic composition, but also to be procurable on a large scale. Thus, close to identical animals were needed in vast numbers. Trying to meet the emerging needs of identical animals generated national and international efforts to standardize animals both genetically and pathogenically. The animals that were produced for use in routine science came to be known as specific pathogen free animals (SPF), which was a term that specified its standard of health and value as laboratory animal.

To investigate the transformation of laboratory animals in these processes I based the analysis on insights from STS (including actor-network-theory) and history of science, in particular Bruno Latour (1996) and Adele Clarke (1987). I start the story by investigating how laboratory animals became established as crucial tools 


\section{$\$$}

NORDIC JOURNAL

of Science and Technology Studies

for science and how the scientists worked towards establishing a laboratory animal science industry, in particular the building of a large-scale production unit for standardized laboratory animals. Latour's book Aramis, or the love of technology (1996) has been particularly helpful in conceptualizing how a technological project develops (or fail to develop) from vision to reality and the negotiations and challenges involved in realizing new technoscientific objects. Together with Clarke's work that emphasizes the importance of attending to not only the objects of science, but also their infrastructural arrangements, Latour's work and other STS studies have brought the technology to life in the study in terms of recognizing its importance for the realization of scientific knowledge production in the first place. The concept of infrastructural arrangements includes not only the architectonic aspects of science (such as the lab or the animal house), but the research materials, theories, methods, instruments and so on. All of these aspects are part of the infrastructural arrangements of producing science and they are interlinked in complex ways. Even the laboratory animal is part of the infrastructural arrangements (see also Fujimura 1996), exemplified by the significance of maintaining SPF standards, in a way that they were at the same time intrinsically constitutive of the infrastructure and strangely hidden by being one element among a myriad of necessary tools, people and machines.

\section{The role of infrastructures and practices of care in laboratory animal science}

The Norwegian scientists had already in the early 1950 s recognized that a central part of performing disease control was to have proper infrastructures for housing and care for the animals. Housing and using SPF and other specifically defined animals, the control of hygiene became intrinsic to the practices of the animal house. The animal house came to be regarded as an extended part of the laboratory. A constant tinkering was going on to adjust the technological and human infrastructures to the maintenance of the animal's health and quality as laboratory animals.

As the care of laboratory animals became increasingly regarded as a crucial part of scientific knowledge production, new personnel were trained to meet the new standards for laboratory animal husbandry. I argue that the practices of care and the caretakers (animal technicians) became part of the infrastructural arrangements of laboratory animal science. The animal house became dependent on establishing a standard for skilled care performed by the animal technicians as part of a scientific team. Skilled care involved knowledge into the disciplines of biology, veterinary medicine, anatomy, physiology, epidemiology, but also knowing the individual animal in order to identify when the animal was healthy and when it was not. Further, it involved technical skills such as keeping filing systems recording the animals' age, weight, and health, taking routine tests, keeping animals stress free and even killing diseased or "left-over" animals. The practices of caring were thus intimately linked to the goals of maintaining the animals in line with the laboratory animal standard (SPF), and emphasized the role of the animal and the animal technicians as central parts of the practices of producing science. This does not mean that laboratory animal science was an exclusively calculative practice; that the care practices and knowledge production of the animal house and the laboratory were standardized and thus made no room for practices defying the rigid regime of health.

Recent studies in feminist technoscience have on the contrary helped us understand scientific practices and knowledge production not only as calculative but involving unexpected situations that require tinkering and attentiveness (i.e. Mol 2008; Haraway 2008). In this view tinkering is part of calculation practices and challenges the idea of calculative regimes as perceived in the conformist, technocratic sense of the term. Ruth Harrison's (1965) description of animals as machines in the emerging modernized food production systems in the 1960 s is both fitting and not. The laboratory animals can be described as machines constructed to do particular tasks, however to maintain them as useful machines required responsiveness and attentiveness by the animal technicians. The human-animal relation then - the ability of animal technicians to respond to and learn from the animals to keep them healthy - was integrated in the practice of producing and keeping laboratory animals as well as producing reliable science. The technicians were expected to perform multiple forms of caring to maintain practices of calculation.

By attending to how infrastructures were built and practices of care developed and organized inside of or integral to these infrastructures, I was able to trace how the animal was transformed and how it was both an effect of and affected the practices of laboratory animal science. I argue in line with Haraway (2008) that in constructing a standardized laboratory animal science practice, the animal was made into a co-worker; laboratory animals became working animals that needed attention and caring and the animal technicians needed thus to know the individual animals. Even though the housing and use of animals were highly regulated in terms of hygienic concerns and reliable scientific knowledge production, these instrumental relations should not be seen as reductionist in the conventional meaning of the word (e.g. Haraway 2008, Fox Keller 1983).

Relating to the animal as technology in the laboratory can actually mean the exact opposite of this: The animal as technology is more valued in this particular setting than the animal that is not. Tresselt (2011) also points to this in her master thesis, where she show how the utility and use of the laboratory animal helps constitute the animal's value and identity; not just because animal technicians know that their use (possibly) has wider positive consequences in terms of health objectives, but also in order for the animals to perform their so called "labness". By combining the reading of newsletters, animal 
house reports, and scientific and political guidelines and regulations for animal care, and the reading of work in feminist technoscience on care and technology and human-animal relations (i.e. Mol 2008; Mol, Moser, Pols 2010; Haraway 2008; Holmberg \& Ideland 2009), I argue that the animals were constituted as both technologies and natural beings, and that these aspects were intrinsically linked. Even though I wasn't able to observe animal technicians using, handling, and caring for the animals in real-time, I was able to trace how care practices were organized in the animal house and how different forms of care and welfare concerns became part of the scientific practices of experimenting on animals.

For my work the feminist perspectives has drawn attention to the links between organizing bodies and relations and scientific standards and politics of health. They have activated my way of engaging with the material; my way of reading and interpreting the story. It allowed me both to conceptualize and describe the practices of the animal house but also to be attentive to the importance of care as part of the work of standardizing laboratory animal science in the first place and how these mundane practices of science were both innovative and constitutive of public health work.

Paying attention to the texts available to trace these connections were also valuable clues to the status and role of animal technicians and laboratory animals. Even though expertise on husbandry and care practices came to be highly valued in the system of public health science, the animal technicians are as silent in the texts as the animals. Their silence, that is, their absence, in the texts as narrators that make insight in the practices of the animal house possible for the historian, makes for speculative historicizing in many respects. However, as feminist scholars and historians alike have shown, considering the importance of what is not present has an analytical value in itself; it can be indications of the low status of animals and animal technicians in science compared to scientists even though their importance were proved and argued for again and again. This further emphasizes the multiplicity and tension that embodied the standardized laboratory animal.

A combined attentiveness to how work in the animal house was organized and the texts available to reconstruct the negotiations and strategies for doing so, proves to be fruitful to understanding how animals were transformed into compound standards for public health science (as well as in relation to the public concerns on animal welfare, see below). Further, looking at the practices of care and organizing life invites insights to how different welfare concerns developed. Failing to pay attention to such other alternative and perhaps more promising realities, leaves them, as Ingunn Moser has argued, "unrecognized, and so become disarticulated and made absent, and in consequence, become weaker and less real" (2011: 707-708). By combining the ANT approach of trail-sniffing with perspectives from feminist technoscience on how practices of care and tinkering have world-transforming effects, these mundane practices of science became visible and significant. The fruitfulness of attending to mundane practices was particularly evident when investigating the emergence of laboratory animal science as the concerns that presented themselves in care practices could be traced all the way from the infrastructural and practical aspects of housing, the quality and morals of science and society, and the politics of public health; thus, linking humans and animals together in multiple, intricate and experimental ways.

\section{Understanding the controversy of laboratory animals in science and society}

In writing the history of laboratory animals in Norway it was thus necessary to do a double tracing: One of the material practices of the animal house and the laboratory, and the other on how the technoscientific spaces of science were envisioned, built, and organized for public health. Following the animal and how it was organized and made sense of in these different modes of ordering, led me to conclude that the animals were in fact constituted as compound welfare standards as their composition and use depended on multiple forms of care and welfare concerns; animal welfare, public health and welfare, and reliable scientific knowledge production. The materiality of the animal - that is, the genetic and pathogenic composition representing a particular standard of health - became intrinsically linked to the standard of health in the general public and the standard of Norwegian science. To establish a link between human and animal welfare was crucial also in terms of legitimizing the practice in the general public.

Animal experimentation has always been a contested practice, and has regularly been subject to controversies between scientists and parts of the public. By asserting that laboratory animal science was a practice intensely concerned with both human and animal welfare and was driven by scientific expertise and technoscientific infrastructures, scientists were during the 1960 s able to constitute the practice as a fundamentally welfare-oriented endeavor. Despite this rhetoric, critical outcries to the use of animals in experiments escalated during the 1970s in Europe and the US, and ideas of animals having rights were put forward as strategies for protecting animals against being inflicted unnecessary pain. In Norway animal rightists challenged the emerging practice by accusing scientists to be driven by a pure logic of the mind rather than a more sympathetic "logic of the heart". Fostering sentiments that were only linked to the rational mind were dangerous and challenged people's abilities to care for not only other than humans but also fellow humans, the rightists claimed. The issue of animal welfare and rights were according to the critics of animal experimentation a matter of concern in line with discrimination based on race, poverty, and gender. The scientists responded by pointing to the successes of animal-based science as well as the expertise and infrastructures of science, and how important animal-based science was for ensuring prosperity and health. In this view, and by law, the animal's pain did not 


\section{N}

NORDIC JOURNAL

of Science and Technology Studies

outweigh the gain as long as the pain could be alleviated or controlled by skilled care and husbandry practices.

Rather than understanding the conflict as stalemate in a non-productive way, I have argued that the science-public interaction on the issue of laboratory animals have (re-)enforced the rational combination of welfare and economy proposed by the scientists. As the scientists could point to a powerful materiality, the animal rightists could not provide technoscientific solutions to the challenges of public health, and thus were deemed to propose unpromising and unviable futures (Druglitro 2013). STS and ANT resources have been particularly useful to trace the connections between intersecting modes of ordering laboratory animals and to understand how laboratory animals are given multiple (but partially connected) identities in the controversy, but also how, as Fudge has argued, the centrality of practices of ordering animals in human societies to the reconceptualization of ourselves as human beings.' The story of laboratory animal science in Norway is a radical history of the making of the Norwegian welfare state in the aftermath of the 2nd World War, narrated by attending to how humans and animals are co-constructed at the intersections of scientific, public and political actors. The practice of using animals in medical science has been and still is central in generating questions of how to live with animals, how to use animals, and how to link animal bodies to human bodies, thus being highly productive in forming our ideas and practices of human-animal relationships and human-animal natures.

\section{Radical historicizing as attentive historicizing}

To conclude I want to pick up on where I opened this essay, by attending to the call for radical historicizing. I agree with Fudge that there is a need for radical historicizing in terms of including animals and nature in our studies of the social, and to be explicit about it. The history of animals is not merely a trend in the ever-widening reach of historical scholarship; it is much more than that. It is a development of existing debates in the discipline and the social and humanist sciences as well as in human relationships to nature, emphasizing the situatedness of both author and subject matters (Fudge 2002: 5). Even though radical historicizing seems somewhat different from an ANT perspective than from a cultural historian's perspective as proposed by Fudge, the difference should not be overemphasized. Fudge's point about radical historicizing is descriptive of what I have tried to do in my work. That is, to bring an engagement from the present into historical events and issues. A historian has as its job not only to "recapture" the past, but to mobilize the past in order to have impact on issues of the present, for instance such as the massive scale on the use of animals today in science and food production. However, Fudge claims that this could only be done at the expense of the human, by placing the human "next to the animals, rather than as the users of the animals" (p. 15). Radical historicizing from an ANT point of view would be to start from a symmetrical standpoint, as also Fudge proposes, but not at the expense of the human; to write radical histories would not be at the expense of anything (so to speak), as it would be concerned with assembling the matters of concern and materialities in a particular historically situated practice, and trace how these assemblages produce particular contexts or realities. The question of "who is empowered to act, and who is not?» is a better description of the starting point for a historical analysis mobilized by ANT resources (Harbers 2005: 14). Rather than being "managerial" as critics have claimed, I have experienced ANT to be quite the opposite; it opens up for what we can awkwardly call relational imagining. ${ }^{2}$ That is, to imagine richer worlds that can help us break worn-out patterns of experiencing and reasoning. Isn't this what Haraway means when she says that the coupled acts of writing and research is at the same time factual, fictional, and fabulated? (2013).

Fudge's approach is part of the same move as many other scholars working in social science and the humanities today are hoping for in terms of writing the histories and ethnographies of nature and animals. The urge to broaden current historiography including changing how we understand and tell stories of the past comes from many parts of STS, cultural history and the history of science. Geoffrey Bowker said so expressively in a talk at the KULTRANS conference Regimes of Temporality in Oslo in June 2013 that we need to change the stories of the past that we currently live with in order to transform the present and the future. Fudge's claim is the same, so is as I read them Asdal's, Latour's and Haraway's and others. Radical historicizing is to be attentive to whom we invite to take part in our analysis of past events and for what reasons. In the same way as scientists tinker in the animal house, attentive experimentation by the historian is necessary in order to provide rich histories and to take notice of the intricate intermingling of heterogeneous actors and worlds. Including animals in the history of science have proved to do exactly this, but could perhaps be even more radical if paired up more closely with methodological principles offered by actor-network-theory and science and technology studies.

Tone Druglitro is a post-doctoral research fellow at the Centre for Technology, Innovation and Culture, University of Oslo. Her PhD in STS was on the history of laboratory animals in Norway. 


\section{Literature}

Amsterdamska, O. 1990. Surely you are joking, Monsiuor Latour. Science, Technology and Human Values 15 (4): 495-504.

Asdal, K. 2003. The problematic nature of nature: The post-constructivist challenge to environmental history. History and Theory. Theme issue 42: 60-74.

Asdal, K. 2011. Politikkens natur - naturens politikk. Oslo: Universitetsforlaget.

Asdal, K. 2012. Contexts in Action - and the Future of the Past in STS. Science in Context 37 (4): 379-403

Asdal, K. et al 2010. Tekst og historie. Å lese tekster historisk. Oslo: Universitetsforlaget.

Clarke, A. 1987. Research materials and reproductive science in the United States, 1910-1940. In Physiology in the American Context edited by G. Geison. Bethesda MD: American Physiological Society.

Daston, L. 2009. Science Studies and the History of Science. Critical Inquiry, 35 (4): 798-813.

Dear, P. \& Jasanoff, S. 2010. Dismantling Boundaries in Science and Technology Studies. Isis 101: 759-774.

Druglitrø, T. 2013. Motstand mot "forstanden". Kontroversen om forsøksdyr i Norge på 1970-tallet. Materialisten.Tidsskrift for forskning, fagkritikk og teoretisk debatt 40 (3): XX

Druglitrø, T. 2012. Å skape en standard for velferd. Forsøksdyr i norsk biomedisin 1953-1986. PhD thesis. Oslo: Akademika Forlag.

Elam, M. 1999. Living Dangerously with Bruno Latour in a Hybrid World. Theory, Culture and Society 16 (4): 1-24.

Fox Keller, E. 1983. A Feeling for the Organism: The Life and Work of Barbara McClintock. San Francisco: W.H. Freeman and Company.

Fudge, E. 2002. A Left-Handed Blow: Writing the History of Animals. In Rothfels, N (ed.). Representing Animals, 3-18. Bloomington: Indiana University Press.

Fujimura, J. 1996. Crafting Science: A sociohistory of the quest for the genetics of cancer. Cambridge, Mass.: Harvard University Press.

Haraway, D. 2013. Multispecies Cosmopolitics. Staying with the Trouble. Paper given at the 2013 IHR Distinguished Lecture. Available from: http://vimeo.com/62081248

Haraway, D. 2008. When Species Meet. Minneapolis: University of Minnesota Press.
Haraway, D. 1989. Primate Visions. Gender, race and nature in the world of modern science. New York and London: Routledge.

Haraway, D. 1988. Situated Knowledges: The Science Question in Feminism and the Privilege of Partial Perspective. Feminist Studies, 14 (3): 575-599.

Harbers, H. ed. 2005. Inside the Politics of Technology. Agency and Normativity in the Co-Production of Technology and Society. Amsterdam: Amsterdam University Press.

Harrison, R. 1965. Animal Machines. The new factory farming industry. New York: Ballantine Books.

Holmberg \& Ideland, M. 2009. Transgenic silences. The rhetoric of comparisons and transgenic mice as "ordinary treasures". Biosocieties, 4 (2): 165-181.

Horst, M. \& Irwin, A. 2010. Nations at Ease With Radical Knowledge: On Consensus, Consensusing and False Consensusness. Social Studies of Science 40, (1): 105-126.

Irwin, A. 2001. Constructing the scientific citizen: Science and democracy in the biosciences. Public Understanding of Science 10 (1): 1-18.

Jasanoff, S. 2000. Reconstructing the Past, Constructing the Present: Can Science Studies and the History of Science Live Happily Ever After?. Social Studies of Science, 30 (4): 621-631

Kirk, R. G. W. 2004. Reliable Science - Responsible Scientists: Constructing Standard Laboratory Animals in Britain C. 1919-1976. PhD thesis. London: University College London.

Kohler, R. 1994. The Lords of the Fly. Drosophila genetics and the experimental life. Chicago: University of Chicago Press.

Latour, B. 2005. Reassembling the Social. An introduction to actor-network-theory. Oxford: Oxford University Press.

Latour, B. 1996. Aramis, or the love of technology. Cambridge, Mass.: Harvard University Press.

Law, J. 1994. Organizing Modernity. Oxford: Blackwell.

Lynch, M. 1988. Sacrifice and the Transformation of the Animal Body into a Scientific Object: Laboratory Culture and Ritual Practice in the Neurosciences. Social Studies of Science 18 (2): 265-289.

Mol, A. 2008. The logic of care. Health and the problem of patient choice. London: Routledge.

Mol, Moser \& Pols 2010. Care in Practice. Tinkering in Homes, Clinics 
and Farms. Amsterdam: Transkript verlag.

Moser, I. 2011. Dementia and the Limits to Life: Anthropological Sensibilities, STS Interferences, and Possibilities for Action in Care. Science, Technology and Human Values 36 (5): 704-722.

Rader, K. 2004. Making Mice. Standardizing Animals for American
Biomedical Research 1900-1955. New Jersey: Princeton University Press.

Tresselt, H. C. 2011. Keeping the Cares Together: How Animal Technicians Deal with Ethical Dilemmas in the Laboratory. Master thesis. Oslo: Centre for Development and the Environment (SUM) 